\title{
Influence of Employee-Focused Corporate Social Responsibility and Employer Brand on Turnover Intention
}

\author{
Chizoba Bonaventure Okolocha \\ Department of Entrepreneurship Studies, Faculty of Management Sciences, Nnamdi Azikiwe University \\ PMB 5025 Awka, Anambra State, Nigeria
}

\begin{abstract}
The purpose of this paper is to investigate employee turnover intention among small and medium-sized enterprises (SMEs) in Malaysia, where difficulty in retention of employees is recognized as being a major issue for SME managers. This study seeks to focus on the mediation effect of employer brand between corporate social responsibility (CSR) and turnover intention. A literature review on CSR indicates that employer brand and turnover intention provide the basis for the research design and hypotheses. Self-administered questionnaire survey, involving 384 respondents from registered SMEs in Selangor, W.P. Kuala Lumpur, and Johor Bahru were analyzed. This study is significant in two ways: Firstly, the findings supported the relationship between employee-focused CSR and turnover intention. Secondly, employer brand was also a significant mediator between CSR and turnover intention. The study findings are expected to guide SME managers and policy makers on employee related decisions and also provide them with insight on the benefits that could be derived from employee-focused CSR.
\end{abstract}

Keywords: CSR, Employer brand, SMEs, Turnover intention.

DOI: $10.7176 / \mathrm{EJBM} / 12-9-07$

Publication date:March $31^{\text {st }} 2020$

\section{Introduction}

Today's dynamic and competitive business environment had contributed to the relevance of employee-focused corporate social responsibility (CSR) and employer brand in the management of employees' welfare, attitudes and behavior of small and medium size enterprises (SMEs). Farooq, Farooq and Jasimuddin (2014) defined employeefocused corporate social responsibility as "the practices, which send signals and cues that the organization is caring, benevolent and aware of employees' value” (p. 4). Low, Ong and Tan (2017) provided the relationship between employee-focused CSR and turnover intention that employee turnover intention is reduced and attitudinal outcome such as job satisfaction and organizational commitment increased when the company engages in responsible behavior and provides motivation for employees in terms of worker benefits or skill enhancement.

Turnover intentions of employees' have been a critical issue in firms' financial performance and productivity. The SME Annual Report (2013) points out that inadequately educated and skilled workforce is considered as the major constraints to growth and productivity in Malaysia. The business community in the country especially the SMEs face difficulty in recruiting and retaining skilled workers (SME Annual Report, 2013). This corroborates with the view of Wee (2013) that "voluntary employee turnover rate in Malaysia is growing progressively since the year 2008 with $9.3 \%$ to $10.1 \%$ for the year 2009 and $13 \%$ for the year 2010 " (p.36). Turnover which refers to employees leaving the organization or firm, creates a costly problem ranging from a loss of work efficiency and productivity, increase training cost and selection time associated with hiring new employees and other indirect costs (SME Annual Report, 2013). This implication; therefore, requires managers to universally keep watch on employees' turnover intention and to continuously introduce remedies to curb the overall turnover effect on business and organizational performance.

Previous studies such as Low, Ong and Tan (2017); Khan, Zahoor and Irum (2014), and Galbreath (2010) have been carried out on the impact of corporate social responsibility on relevant organizational outcomes such as turnover intention. However, the possible role of employer brand as a mediator in explaining corporate social responsibility and turnover intention relationship seems not to be explored. According to Ambler and Barrow (1996), employer brand is defined as "the package of functional, economic and psychological benefits provided by employment and identified with the employing company" (p.187). Kashikar-Rao (2014) emphasized that CSR is emerging as a very important component of employer brand. For instance, studies such as Galbreath (2010) and Khan et al. (2014) revealed that CSR had a significant and negative relationship with turnover intention. However, all these studies have failed to investigate the mediating role of perceived employer brand in explaining the relationship between CSR and turnover intention. Hence, this study bridge this gap by focusing on the influence of employee-focused CSR on turnover intention and also investigates the mediating role of perceived employer brand in the relationship between employee-focused CSR and turnover intention.

CSR in SMEs has received little scholarly attention. Supported by Liu and Fong (2010) "that quantitative and qualitative research with respect to CSR in SMEs is limited, especially in developing countries" (p.34). The majority of the studies in this area of research have been concentrated on larger firms (for example, Hansen, Dunford, Boss, Boss \& Angermeier, 2011; Bourdeau, Graf \& Turcotte, 2013; Chon \& Yoo, 2013). For instance, 
Bashir, Hassan and Cheema (2012) revealed that a large number of medium size organizations' employees were not aware of CSR in their organization. With the gaps identified, this study seeks to answer the following questions: (1) Do employee-focused CSR practices lead to lower turnover intention among employees in SMEs? (2) What is the relationship between employee-focused CSR, perceived employer brand and turnover intention? (3) Does perceived employer brand mediate the relationship between employee-focused CSR and turnover intention?

\section{Research Background}

The growing importance of employee-focused CSR and employer brand has implication for SME managers. SME managers in the context of this study are either the owners of the business or individuals appointed by the owners to oversee the affairs of the business either in the production or service industry. For instance, Kashikar-Rao (2014) emphasized that CSR is increasingly emerging as an important component of management practices not only in large but small businesses as well. In Malaysia, SMEs are important to the country's economy as they accounted for $99.2 \%$ of total business establishments, contributes significantly to $59 \%$ of total employment, $32 \%$ of the gross domestic product and 19\% of the total export value (Star online, 2013; Wee, 2013). According to SME corporation Malaysia (2014), small and medium size enterprises are small businesses whose sales turnover are limited to RM50 million with workers not exceeding 200 employees for manufacturing sectors, while service and other sectors sales turnover and employee are limited to RM20 million and 75 workers respectively.

The benefits of CSR have become imperative to the success of all types of small and medium, and large organizations (Khan et al., 2014). Employee-focused CSR through its legitimate and persuasive characteristics is very important to SME towards retaining employees, especially when the sector is confronted with challenges of recruitment and retention of skilled labor force needed to drive productivity, innovation and contribute to general societal well-being and nation building (APEC, 1994; Small and medium industries development corporation Malaysia, 2002; Ting, 2004; \& SME Annual Report, 2013). For instance, Kashikar-Rao (2014) emphasized that CSR practices are increasingly emerging as an important component of employer brand both in large and small businesses. This is because CSR practices help companies create strong and positive employer brand relevant for retention of great talent (Dokania \& Pathak, 2013). There is a crucial need for SMEs as an engine hub for employment and economic growth to have a deep understanding on the relevance of CSR towards the creation of positive employer brand image and favorable employee job attitudes, behaviors and organizational outcomes. This is in accordance with Saxena (2014) whose findings revealed that a strong employer brand had a positive impact on employee job satisfaction, commitment, loyalty and retention.

Employees play an important role in every business success as well as in building a relationship with other stakeholders (Schlager, Bodderas, Maas, \& Luc Cachelin, 2011). They also play a crucial role in exercising CSR strategies (Farooq et al., 2014). Hence, understanding the strategies to retain important stakeholders such as employees and subsequently reduce their turnover intention becomes imperative and creates the need for the present study. Joarder and Ashraf (2012) defined turnover intention "as employees voluntary cessation of membership of an organization and it's their freedom that they can leave the organization for any reasons such as work environmental factors, career issues or may be influenced by the external opportunities" (p. 21).

Corporate social responsibility over the years has been proven to lower turnover intention and attracts great talents. This is largely because of strong employer brand image derived from CSR initiatives (Kashikar-Rao, 2014; Dokania \& Pathak, 2013 \& Priyadarshi, 2011). According to Kashikar-Rao (2014), "the strategic implementation of CSR initiatives involving the employees does not only create a social awareness among the employees but creates a sense of belongingness towards the organizations and adds to the positive brand image of the organization in the minds of existing employees and the society" (p.194). Managing employer brand is imperative for a business organization as it captures the value proposition of an employer or organization that engages current and prospective employees. For instance, the findings by Kashikar-Rao (2014) revealed that 95\% of respondents (employees) who were actively involved or participated in CSR initiatives indicated that they were motivated by the good reputation of their employer brand as a result of perceived CSR initiatives.

\section{Hypotheses Development}

\subsection{CSR and Turnover Intention}

CSR, as it relates to employees has become a vital tool towards retention of employees (Galbreath, 2010; Bourdeau, Graf \& Turcottee, 2013; Chon \& Yoo, 2013). For instance, Khan et al. (2014) carried out their study on employee behaviors towards CSR and found out that employees' positive perception of CSR tended to reduce their intention to leave their employer or organization. A similar study such as Galbreath (2010) and Low et al. (2017) also provided support for the negative relationship between CSR and turnover intention, with empirical evidence that the practice of corporate social responsibility did reduce employee turnover. This is in accordance with the social exchange theory which stated that a positive social exchange in a relationship would give rise to favorable outcomes to parties in a relationship (Homans, 1958). Based on the social exchange theory, responding to employees' needs taking into cognizance employees' valuable input such as time, knowledge, commitment 
through socially responsible behavior by an employer might result in a positive outcome such as their intention to remain with a specific employer or organization. Thus, the following hypothesis was developed:

H1: There is a negative relationship between employee-focused CSR and turnover intention.

\subsection{CSR and Employer Brand}

CSR is a dominant issue with relevance towards employees' management and business survival (Khan et al., 2014 \& Galbreath, 2010). Dokania and Pathak (2013) pointed out that employees, as a valuable asset of any business organization require retention and development for business success. According to Kashikar-Rao (2014), "the employer's good reputation built up due to good working conditions, competitive compensation packages and good reputation of being socially responsible are drivers of employer brand" (p. 189). Dokania and Pathak (2013) also provided similar findings and supported that CSR, as perceived by employees had a positive relationship with employer brand. According to Dokania and Pathak (2013), "CSR help companies to create a strong employer brand which does not only help retain and motivate current employee but also attract potential employees" ( $p$. 153). This is in accordance with cognitive dissonance theory, which states that individuals seek internal consistency between their expectations and reality (Festinger, 1957). Relying on the cognitive dissonance theory, it is expected that CSR initiatives focused on employees will help develop positive behaviors among employee, hence reduce employee dissonance or negative perception about an employer. This is because according to the cognitive dissonance theory such responsible practices that are in line with employee values, beliefs and expectations will help discourage employee dissonance and negative behaviors. Hence, it is hypothesized that: $\mathrm{H} 2$ : There is a positive relationship between employee-focused corporate social responsibility and perceived employer brand.

\subsection{Employer Brand and Turnover Intention}

The concept of employer brand has transformed from what is traditionally known as a marketing tool to a robust human resource strategy towards acquisition and retention of great talents (Dokania \& Pathak, 2013). This could be because of a positive impression that employer brand leaves in the mind of employees, hence providing a psychological anchor that promotes strong identification and discourages turnover intention. Kashyap and Rangnekar (2016) and Sokro (2012) provided similar findings and support that employer brand as perceived by employees had a significant and negative relationship with turnover intention. This creates the need for business organizations to pay crucial attention to their brand image, as strong and positive employer image might be instrumental in lowering turnover intention (Kashyap \& Rangnekar, 2016). Relying on the social identity theory, a person's self-concept is to a great extent derived from their membership in the various groups (Tajfel \& Turner, 1986). Hence, employees continuously seek and enhance their social concept, social identity, and self-esteem by identifying with an organization which has a positive employer brand. Thus, the following hypothesis is formulated: H3: There is a negative relationship between perceived employer brand and turnover intention.

\subsection{The Mediating Effect of Employer Brand on the relationship between Employee-Focused CSR and Turnover Intention}

The role of CSR towards creating an employer brand is becoming enormous and imperative for all business organizations. A strong employer brand is formidable towards talent attraction and retention (Kashikar-Rao, 2014). The relationship between employee-focused CSR and turnover intention is hypothesized to be mediated by perceived employer brand in this study. Relying on the social identity theory, CSR activities reduce turnover intention because CSR helps to build a strong brand name for the company (Dokania \& Pathak, 2013; Tajfel \& Turner, 1986). Company CSR engagement is expected to increase the brand name of the organization which then results in lower turnover as more employees want to be associated with a positive brand name. Priyadarshi (2011) pointed out that "employees perception of his or her employer image is shaped by personal and professional experiences and this in many ways would determine his/her attitude and consequently his/her behavior" (p. 519). Based on the following arguments, the following hypothesis is developed:

H4: Employer brand mediates the relationship between employee-focused CSR and turnover intentions. 


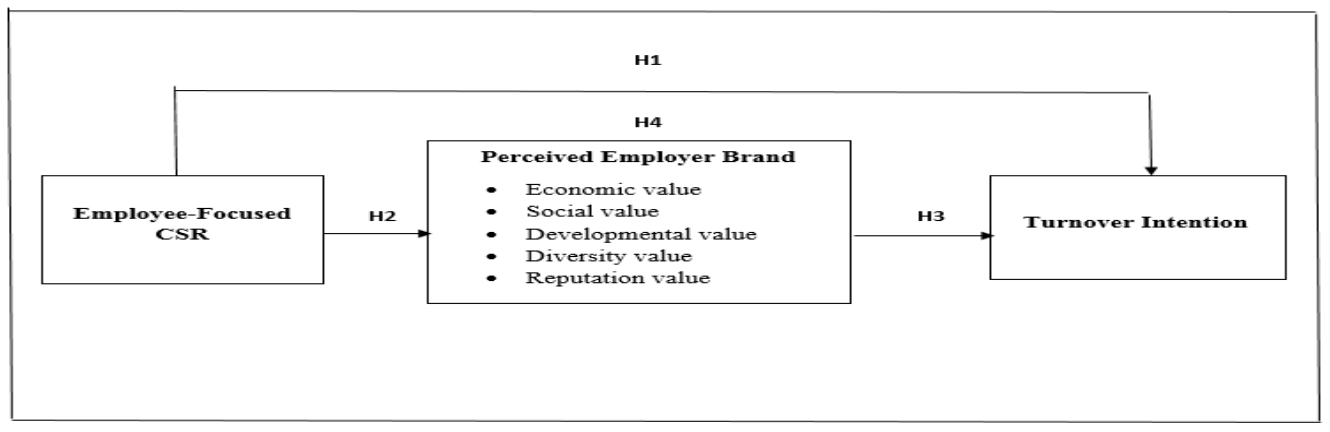
Adapted from Khan, Zahoor and Irum (2014) and Schlager, Maas and Luc Cachelin

Figure 1. Research Framework

\section{Research Methodology}

The study involved SMEs operating in three states with the highest concentration of SMEs namely, Selangor, W.P. Kuala Lumpur and Johor Bahru based on SME Corporation Malaysia's database. These three states accounted for $43.3 \%$ of the total SMEs operating in Malaysia (Refer to Table 1 below).

Table 1: Population and Percentage of SMEs in Selangor, W.P. Kuala Lumpur, and Johor Bahru

\begin{tabular}{|c|c|c|}
\hline States & Total number of SMEs & $\%$ \\
\hline 1. Selangor & 125,904 & 20 \\
\hline 2. W.P. Kuala Lumpur & 84,261 & 13 \\
\hline 3. Johor Bahru & 68,874 & 11 \\
\hline Total & 279,039 & 43 \\
\hline
\end{tabular}

Source: Economic/SMEs Census, 2011 by Department of Statistics, Malaysia

\subsection{Sample and Sampling Techniques}

The sample size for this study was 384 employees. This was determined using the Raosoft on-line sample size calculator with a confidence level of $95 \%$. Firstly, due to low response rate associated with postage survey (Zikmund, 2000), the researcher tripled the sample size of 384 by administering three questionnaires to three employees in each randomly selected SME, hence, increasing the total questionnaire distributed to 1,152 questionnaires. Secondly, the total number of questionnaires that was distributed in each state was determined by proportioning the percentage of SMEs in each state with the total questionnaires. Below is the total number of questionnaires that was distributed to each state. (Refer to Table 2).

Table 2: Number of SMEs and Questionnaires to be distributed to the 3 States

\begin{tabular}{|c|c|c|c|c|}
\hline State & $\begin{array}{c}\text { Total Number of } \\
\text { SMEs }\end{array}$ & $\begin{array}{c}\text { \% of total } \\
\text { questionnaires } \\
\text { distributed }\end{array}$ & $\begin{array}{c}\text { No of questionnaires } \\
\text { distributed }\end{array}$ & $\begin{array}{c}\text { No of SMEs } \\
\text { targeted per } \\
\text { state }\end{array}$ \\
\hline Selangor & 125,904 & 45 & $1,152 \times 0.45=518$ & $518 / 3=173$ \\
\hline WP Kuala Lumpur & 84,261 & 30 & $1,152 \times 0.3=346$ & $346 / 3=115$ \\
\hline Johor Bahru & 68,874 & 25 & $1,152 \times 0.25=288$ & $288 / 3=96$ \\
\hline Total & 279,039 & 100 & 1,152 questionnaires & 384 SMEs \\
\hline
\end{tabular}

For the purpose of this study, a multi-stage sampling technique was adopted. Stage 1 involved selecting the states with the highest concentration of SMEs. Stage 2 involved the selection of companies using simple random sampling where the SMEs were randomly selected for participation within each cluster. Stage 3 involved selection of employees within the company. This was carried out using judgmental sampling where employees who had worked for more than one year in the organization were selected to participate in the survey. This was because the employees who had stayed for one year in their organization were assumed to have better knowledge of their company policies such as CSR initiatives.

\subsection{Data Collection}

Self-administered and postal surveys were used to collect data from current employees of SMEs working in three different states namely, Selangor, W.P. Kuala Lumpur, and Johor Bahru. The survey method was used as it would help predict the relationship among variables and develop a model for such relationship (Saunders, Lewis, \& Thornhill, 2012). It also provided an inexpensive, reliable and fast approach in assessing parameters about the population (Zikmund, 2000).

A letter explaining the purpose and importance of the present study was sent to SME managers to encourage their participation. Instructions were provided to employees on how to fill the questionnaire. The respondents were 
given one week to complete the distributed questionnaires. Follow-up phone calls to the employees were made to encourage more participation in the survey. Of the 1,152 questionnaires distributed, 519 questionnaires were received and 498 questionnaires were usable.

\subsection{Measures}

Employee-focused corporate social responsibility was measured using 12 items CSR measurement scale from (Turker, 2009). Sample questions included, "My company provides a wide range of indirect benefits to improve the quality of employees' lives", "The employees in my company receive a reasonable salary to maintain an acceptable quality of life" and "My company's policies provide a safe and healthy working environment to all its employees". The scale used for the items was a five-point Likert-scale where $1=$ strongly disagree and 5= strongly agree. The Cronbach alpha score was 0.92 (Khan et al., 2014).

Employer brand was assessed using items from Berthon, Ewing and Hah (2005) and Schlager et al. (2011). These items were used to evaluate the perception of an employee on five aspects of employer brand, which were economic value, developmental value, social value, diversity value, and reputation value. Sample questions included "My company provides a good salary in my place of work", "My employer made provision for good retirement benefits and "My employer offers a fair amount of vacation to me". All data was collected and quantified using five-point Likert-scale where $1=$ strongly disagree and $5=$ strongly agree. The Cronbach's alpha score was 0.96 (Arachchige \& Robertson, 2011).

Turnover intention was assessed using four items from Hom and Griffeth (1991) and sample questions included, "During the next six months, I intend to search for another full-time job", "I intend to leave this organization during the next six months", "I regularly think of quitting my job" and "The thoughts of quitting my place of work seldom cross my mind". All data was collected and quantified using five-point Likert-scales where $1=$ strongly disagree and $5=$ strongly agree. The scale has been frequently used in past studies, with a reliability ranging from 0.87 to 0.97 (e.g. Mitchell, Holtom, Lee, Sablynski \& Erez, 2001; Holtom \& O’Neill, 2004; TianForeman, 2009; Khan et al., 2014). Demographic data covering age, gender, education level, ethnicity, position (managerial and non-managerial) and industry was also collected.

The questionnaire was available in two languages: English and Bahasa Melayu. Back translation was used to check if the translated items matched the original English version of the items. The questionnaire was pilot tested before the actual data collection to ensure that proposed methods or instruments are appropriate for this study and not too complicated (Van Teijilingen \& Hundley, 2001).

\section{Results}

SPSS version 20 was used to analyze the results and test the hypotheses of this study.

\subsection{Reliability}

Table 3 shows the reliability of the variables used in this study. The three variables were employee-focused CSR, employer brand and turnover intention. Since all Cronbach's Alpha values were greater than 0.70 (Refer to Table 3 ), this shows that there was an internal consistency in the instruments (Hair, Black \& Anderson, 2010).

\begin{tabular}{ccc}
\hline Description & Number of items & Cronbach's Alpha \\
CSR & 12 & 0.95 \\
Employer brand & 23 & 0.96 \\
Turnover intention & 4 & 0.87 \\
\hline
\end{tabular}

Table 3: Reliability Scores

\subsection{Descriptive Analysis and Correlation Analysis}

Table 4 indicated that respondents had a moderate perception of their company's CSR initiatives with the mean value of 3.20. Similarly, respondents also had a moderate perception of employer's brand with a mean value of 3.40. However, respondents appeared to be low on their intention to leave their organizations with a mean value of 2.74. For all three variables of corporate social responsibility, perceived employer brand and turnover intention, the higher the scores, the higher the employees' perception of the variables measured. In order to have an insight on the proposed relationship, correlation analysis test was conducted. Correlation coefficients $(r)$ among variables under study are displayed in Table 4. Correlation statistics revealed a strong correlation among the variables studied. 
Table 4: Descriptive Statistics and Correlation Matrix of Variables $(\mathrm{N}=498)$

\begin{tabular}{lccccc}
\hline Variable & CSR & PEB & TI & Mean & SD \\
\hline CSR & 1.00 & & & 3.20 & 1.10 \\
PEB & $0.91^{*}$ & 1.00 & & 3.40 & 0.96 \\
TI & $-0.85^{*}$ & $-0.83^{*}$ & 1.00 & 2.74 & 1.31 \\
\hline
\end{tabular}

* Significant at 0.01 level.

$\mathrm{CSR}=$ Corporate social responsibility $\mathrm{PEB}=$ Perceived employer brand; $\mathrm{TI}=$ Turnover intention .

\subsection{Hypothesis Testing}

In order to test the proposed hypotheses in the current study, multiple regression analysis was performed to test hypotheses H1 to H3. To test the mediating effect of perceived employer brand (PEB) on the relationship between employee-focused CSR and turnover intention (TI), Baron and Kenny (1986) four-step regression was used. According to Baron and Kenny (1986), the following four steps are proposed to test the mediation effect:

Step 1. To test the relationship between independent variable (CSR) and dependent variable (TI).

Step 2. To test the relationship between independent variable (CSR) and mediating variable (PEB)

Step 3. To test the relationship between independent variable (CSR), (PEB) and dependent variable (TI)

Step 4. To test the mediation effect using Sobel test

In step 1, turnover intention was regressed on CSR. The relationship between these variables was found to be significant and negative with $(\beta=-0.85, t=-36.62, p<0.05)$. Hence, H1 is supported and satisfying the first condition for mediation analysis (Refer to Table 5).

In step 2, perceived employer brand was regressed on CSR. The relationship was significant and positive $(\beta=$ $0.90, t=48.50, p<0.05$ ). Hence, the results provided support for $\mathrm{H} 2$ (Refer to Table 5).

In step 3, turnover intention was regressed on CSR and perceived employer brand. Table 8 indicates that PEB which $(\beta=-0.32, t=-5.90, p<0.05)$ emerged as a significant predictor of turnover intention. Hence, the results provided support for H3. Further, CSR and turnover intention relationship became weakened (from $\beta=-0.85$, $p<0.05$ to $\beta=-0.56, p<0.05)$, but still remained significant when the effects of mediating variable PEB was controlled; hence, suggesting a partial mediation. Therefore, H4 is supported and satisfied the third step for mediation analysis. The $\left(r^{2}\right)$ of the last step mediation model explained 74.8 percent variance indicating that 74.8 percent variance in turnover intention was explained by CSR and perceived employer brand (Refer to Table 5). In step 4, Sobel test was performed to confirm the significant of the mediator (PEB) in explaining CSR and turnover intention relationship. Sobel test result of $(t=5.86, p<0.01)$ indicates that perceived employer brand significantly and partially mediates the relationship between CSR and turnover intention.

Table 5: Regression results using Baron and Kenny four step mediation test

\begin{tabular}{lcccc} 
Variables & $\beta$ & $t$-value & $R^{2}$ & $p$-value \\
Step 1: CSR on TI & -0.85 & -36.62 & 0.73 & 0.00 \\
Step 2: CSR on PEB & 0.90 & 48.50 & 0.82 & 0.00 \\
& & & 0.74 & 0.00 \\
Step 3: CSR, PEB on TI & -0.56 & -10.42 & & \\
& -0.32 & -5.90 & & \\
\hline
\end{tabular}

Note: $p<0.05$ significance level

$\mathrm{CSR}=$ Corporate social responsibility; $\mathrm{PEB}=$ Perceived employer brand; $\mathrm{TI}=$ Turnover intention .

\section{Discussions and Conclusion}

This study provided evidence on the applicability of CSR initiatives in SMEs. The four hypotheses proposed in the present study were all supported. The four hypotheses were the relationship between CSR and turnover intention, the relationship between CSR and employer brand, the relationship between perceived employer brand and turnover intention as well as the mediation effect of employer brand on the relationship between CSR and turnover intention. In conclusion, this study has revealed that SME employee turnover intention was influenced by CSR and employer brand. Hence, CSR becomes an important strategy for SME managers towards the creation of positive employer brand image relevant for attraction and retention of talent in SMEs.

\subsection{Theoretical Implications}

This research contributes to existing literature on CSR and turnover intention relationship. Scholars have considerably written on the relationship between CSR and turnover intention. Examples of these studies are Galbreath (2010), Khan et al. (2014), Chon and Yoo (2013), Bourdeau et al. (2013) and Hansen et al. (2011). According to Hansen et al. (2011) and Khan et al. (2014), there is a need to explore more attitudinal level outcome 
that reflects both the interest of the employers and employees such as attitudes, perception, image and identity in gaining more understanding of the relationship between CSR and turnover intention. Hence, this study contributes to the body of knowledge through investigating the process upon which CSR influences turnover intention taking into cognizance the mediating role of employer brand. Firstly, the study led to support Khan et al. (2014) CSR model where CSR did significantly influence turnover intention. Secondly, this study also found that employer brand partially mediates the relationship between CSR and turnover, hence extending the findings of Khan et al. (2014).

Secondly, most CSR and turnover intention studies appear to focus more on large firms. (e.g.: Hansen et al., 2011; Galbreath, 2010; Khan et al., 2014). Fraj-Andres, Lopez-Perez, Melero-Polo and Vazquez-Carrasco (2012) has argued extensively that characteristics of a large firm and small firm vary in terms of "number of employees, assets, financial turnover, market share and ownership structure" (p. 269). This study contributes to the context of existing literature on CSR and turnover intention by investigating CSR and turnover intention relationship from SME's perspective.

\subsection{Managerial Implications}

The findings of the present study are of immense benefits to SME owners and managers. Based on the study analysis, CSR does enhance employer brand image and as well reduces turnover intention of employees. This has significant implication for SME managers, as the findings of this study are expected to guide SMEs owners and managers decisions on employees related issue through providing SMEs owners and managers with empirical knowledge and understanding of employee values and benefits associated with engaging in employee-focused CSR and how such practices are relevant in managing human resource which includes retention. The findings of this study have also proven to SME managers that CSR benefits exceed employee benefit to include organization benefit such as positive employer brand image. Kashikar-Rao (2014) has pointed out employer brand as the strength of an organization.

CSR strategies could help bring about positive employee response and behavior such as improved retention rate (Galbreath, 2010), job satisfaction (Bordeau et al., 2013), employer brand (Kashikar-Rao, 2014), organizational commitment (Chon \& Yoo, 2013) and organizational citizenship behavior (Khan et al., 2014). This corroborates with the views of Tsai, Tsang and Cheng (2012) that a well-formulated and implemented employeefocused CSR can reduce cost in areas of employee retention and recruitment. This is because according to social exchange theory, employee will respond to CSR relying on the cognitive evaluation of the favorability of exchange of resources and effort involved in an employer-employee relationship. In addition, CSR as an important concept possesses a moral, legitimate and persuasive attribute that is capable of forming a psychological contract and anchor between an employer and employee.

\subsection{Limitations and Future Directions}

The first limitation of this study is that it is cross-sectional in nature. All of the variables were measured at the same time and hence, makes it difficult to infer any casual relationships. For instance, it would be beneficial to know that how employee- focused CSR and employer brand experience by employees could influence their intention to leave after some period. Thus, it is suggested that future research use a longitudinal design for examining the impact of CSR on turnover intention through the mediation effect of perceived employer brand. A longitudinal design would provide additional clarification about how these variables develop over time.

The current study did not investigate the possible gender influence on the examined relationships. Hence, future study is needed to confirm how male and female employees' perception of CSR initiatives influences their perception of employer image and turnover intention. For instance, Chon and Yoo (2013) findings revealed that women are likely to be more influenced by CSR activities. Hence, the researcher suggests an investigation into the moderation role of gender difference in CSR and turnover intention relationship.

Another area of future research is to take into consideration the dimensions of employer brand. Prospective researchers are recommended to test the relationship between each dimension of employer brand and turnover intention. Examples of these perceived employer brand dimensions are economic value, social value, development value, diversity value and reputation value (Schlager et al., 2011).

\section{References}

Ambler, T. and Barrow, S. (1996), “The Employer Brand”, Journal of Brand Management, Vol. 4 No. 3, pp. $185-$ 206.

APEC. (1994), "The APEC survey on Small and Medium Enterprises: Member Report Malaysia”, available at http://www.actetme.org/archive/smesurvey.html (accessed 12 January 2015).

Arachchige, B.J. and Robertson, A. (2011), "Business student perceptions of a preferred employer: A study identifying determinants of employer branding", The IUP Journal of Brand Management, Vol. 8 No. 3, pp. 25-46. 
Baron, R.M. and Kenny, D.A. (1986), "The moderator-mediator variable distinction in social psychological research: Conceptual, strategic, and statistical considerations", Journal of Personality and Social Psychology, Vol. 51 No. 6, pp. 1173-1182.

Bashir, R., Hassan, A. and Cheema, F.E.A. (2012), "Impact of corporate social responsibility activities over the employees of the organizations: an exploratory study", Journal of Management and Social Sciences, Vol. 8 No. 2, pp. 11-21.

Berthon, P., Ewing, M. and Hah, L.L. (2005), "Captivating company: dimensions of attractiveness in employer branding”, International Journal of Advertising, Vol. 24 No. 2, pp. 151-172.

Bourdeau, B., Graf, R. and Turcotte, M.F. (2013), "Influence of corporate social responsibility as perceived by salespeople on their ethical behavior, attitudes and their turnover intentions", Journal of Business \& Economics Research, Vol. 11 No. 8, pp. 358-366.

Chon, M.L. and Yoo, J.M. (2013), "The Internal Impact of CSR on Employees: The Moderating Effect of Gender Difference", Journal of Convergence Information Technology, Vol. 8 No. 13, pp. 512-515.

Dokania, A.K. and Pathak, G.S. (2013), "Corporate Social Responsibility and Employer Branding: A Case Study of Indian Information Technology Industry”, Review of HRM, Vol. 2 No. 1, pp. 149-158.

Farooq, M., Farooq, O. and Jasimuddin, S.M. (2014), "Employees response to corporate social responsibility: Exploring the role of employees' collectivist orientation", European Management Journal, Vol. 32 No. 6 , pp. 916-927.

Festinger, L. (1957), A Theory of cognitive dissonance. Stanford, CA: Stanford University Press.

Fraj-Andres, E., Lopez-Perez, M.E., Melero-Polo, I. and Vázquez-Carrasco, R. (2012), "Company image and corporate social responsibility: reflecting with SMEs' managers", Marketing Intelligence \& Planning, Vol. 30 No. 2, pp. 266-280.

Galbreath, J. (2010), "How does corporate social responsibility benefit firms? Evidence from Australia", European Business Review, Vol. 22 No. 4, pp. 411-431

Hair, J.F., Black, W.C. and Anderson, R.E. (2010). Multivariate Data Analysis: Global Perspectives, PrentinceHall, Englewood Cliffs, NJ.

Hansen, S.D., Dunford, B.B., Boss, A.D., Boss, R.W. and Angermeier, I. (2011), "Corporate social responsibility and the benefits of employee trust: A cross-disciplinary perspective", Journal of Business Ethics, Vol. 102 No. 1 , pp. 29-45.

Holtom, B.C. and O’Neill, B.S. (2004), “Job embeddedness: A theoretical foundation for developing a comprehensive nurse retention plan”, Journal of Nursing Administration, Vol. 34 No. 5, pp. 216-227.

Hom, P.W. and Griffeth, R.W. (1991), "Structural equations modeling test of a turnover theory: Cross-sectional and longitudinal analyses", Journal of Applied Psychology, Vol. 76 No. 3, pp. 350-366.

Homans, G.C. (1958), "Social behavior as exchange”, American Journal of Sociology, Vol. 63 No. 3, pp. 597-606.

Joarder, D.M.H.R. and Ashraf, M.A. (2012), "Work Satisfaction and Employee Turnover Intentions: An Empirical Study”, East West Journal of Business and Social Studies, Vol. 3 No. 1, pp. 19-36.

Kashikar-Rao, M. (2014), "Role of CSR in Employer Branding: Emerging Paradigm", Review of HRM, Vol. 3 No. 1, pp. 188-195.

Kashyap, V. and Rangnekar, S. (2016), "The mediating role of trust: Investigating the relationships among employer brand perception and turnover intentions", Global Business Review, Vol. 17 No. 3, pp. 64S-75S.

Khan, H.A., Zahoor, A. and Irum, S. (2014), "Impacts of Corporate Social Responsibility on Employees Behavior in Telecom sector of Pakistan", European Journal of Business and Management, Vol. 6 No. 11, pp. 34-43.

Liu, H. and Fong, M. (2010) "The corporate social responsibility orientation of Chinese small and medium enterprises", Journal of Business Systems, Governance \& Ethics, Vol. 5 No. 3, pp. 33-50.

Low, M.P., Ong, S.F., \& Tan, P.M. (2017), "Would Internal Corporate Social Responsibility make a Difference in Professional Service Industry Employees' Turnover Intention? A Two-Stage Approach Using PLS-SEM”, Business and Management Research: An International Journal, Vol. 9 No. 1, pp. 24-41.

Mitchell, T.R., Holtom, B.C., Lee, T.W., Sablynski, C.J. and Erez, M. (2001), "Why people stay: Using job embeddedness to predict voluntary turnover", Academy of Management Journal, Vol. 44 No. 6, pp. 11021121.

Priyadarshi, P. (2011), "Employer brand image as a predictor of employee satisfaction, affective commitment \& turnover", Indian Journal of Industrial Relations, Vol. 6 No. 3, pp. 510-522.

Saunders, M., Lewis, P., and Thornhill, A. (2012), Research Methods for Business, Pearson Education Limited, United Kingdom, UK.

Saxena, S. (2014), "Employer branding and its impact on employees", International Journal of Management, IT, and Engineering, Vol. 4 No. 10, pp. 262-275.

Schlager, T., Bodderas, M., Maas, P. and Luc Cachelin, J. (2011), "The influence of the employer brand on employee attitudes relevant for service branding: an empirical investigation", Journal of Services Marketing, Vol. 25 No. 7, pp. 497-508. 
Small and Medium Industries Development Corporation Malaysia. (2002), SME performance report, Small and medium development corporation, Percetakan Nasional Malaysia Berhad, Kuala Lumpur, KL

SME Annual Report (2013), SME annual Report, National SME Development Council, Kuala Lumpur, KL

SME Corporation Malaysia (2014), "New SME Definition 2014”, available at http://sme.corp.gov.my (accessed 20 March 2015).

Sokro, E. (2012), "Impact of employer branding on employee attraction and retention", European Journal of Business and Management, Vol. 4 No. 18, pp. 164-173.

Star online (2013), "SME master plan set to boost sectors growth 2013", available at: http://www.thestar.com.my/news/community/2013/01/01/SME-masterplan-set-to-boost-sectors-growth (accessed 12 April 2015).

Tajfel, H. and Turner, J.C. (1986), the social identity of inter-group behavior. Chicago: Nelson-Hall.

Tian-Foreman, W. (2009), "Job satisfaction and turnover in the Chinese retail industry", Chinese Management Studies, Vol. 3 No.4, pp. 356-378.

Ting, O.K. (2004), "SMEs in Malaysia: Pivot points for Change", available at http://www/mca.org.my (accessed 12 January 2015).

Tsai, H., Tsang, N.K. and Cheng, S.K. (2012), "Hotel employees' perceptions on corporate social responsibility: The case of Hong Kong", International Journal of Hospitality Management, Vol. 31 No. 4, pp. 1143-1154.

Turker, D. (2009), "Measuring corporate social responsibility: A scale development study", Journal of Business Ethics, Vol. 85 No. 4, pp. 411-427.

Van Teijlingen, E. and Hundley, V. (2001), "the importance of pilot studies", Social Research Update, Vol. 35 No. 1, pp. 1-4.

Von weltzien Hoivik, H. and Shankar, D. (2011), "How can SMEs in a cluster respond to global demands for corporate responsibility? Journal of Business Ethics, Vol. 101 No. 2, pp. 175-195.

Wee, T.C. (2013), "Talent Retention: The Pressures in Malaysia SMEs", American Journal of Economics, Vol. 3 No. 5 , pp. $35-40$.

Zikmund, W.G. (2000), Business Research Methods, Dryden Press, United States of America, USA. 